\title{
Metoprolol and bisoprolol ameliorate hypertrophy of neonatal rat cardiomyocytes induced by high glucose via the $\mathrm{PKC} / \mathrm{NF}-\mathrm{\kappa} \mathrm{B} / \mathrm{c}-\mathrm{fos}$ signaling pathway
}

\author{
MIN WANG ${ }^{*}$, QINGBO LV*, LIDING ZHAO, YAO WANG, YI LUAN, \\ ZHENGWEI LI, GUOSHENG FU and WENBIN ZHANG
}

\begin{abstract}
Key Laboratory of Cardiovascular Intervention and Regenerative Medicine of Zhejiang, Department of Cardiology, Sir Run Run Shaw Hospital, School of Medicine, Zhejiang University, Hangzhou, Zhejiang 310027, P.R. China
\end{abstract}

Received February 13, 2019; Accepted November 1, 2019

DOI: $10.3892 /$ etm.2019.8312

\begin{abstract}
Hyperglycemia caused by diabetes mellitus could increase the risk of diabetic cardiomyopathy. However, to the best of our knowledge, the underlying mechanism of this process is still not fully explored. Thus, developing ways to prevent hyperglycemia can be beneficial for diabetic patients. The present study was designed to investigate the influence of metoprolol and bisoprolol on the cardiomyocytic hypertrophy of neonatal rat cardiomyocytes. Cardiomyocytes were cultured in two types of media: One with low glucose levels and one with high glucose levels. Cardiomyocytes cultured in high glucose were further treated with the following: A protein kinase $\mathrm{C}(\mathrm{PKC})$ inhibitor, an NF- $\kappa \mathrm{B}$ inhibitor, metoprolol or bisoprolol. The pulsatile frequency, cellular diameter and surface area of cardiomyocytes were measured. Protein content and $\left[{ }^{3} \mathrm{H}\right]$-leucine incorporation were determined, atrial natriuretic peptide (ANP), $\alpha$-myosin heavy chain $(\alpha-\mathrm{MHC})$ and $\beta$-myosin heavy chain ( $\beta$-MHC) mRNA levels were calculated by reverse transcription-quantitative PCR, while the expression and activation of PKC- $\alpha$, PKC- $\beta_{2}, \mathrm{NF}-\mathrm{\kappa B}$, tumor necrosis factor- $\alpha$ (TNF- $\alpha$ ), and c-fos were detected by western blotting. Metoprolol or bisoprolol were also used in combination with PKC inhibitor or NF- $\mathrm{kB}$ inhibitor to determine whether the hypertrophic response would be attenuated to a lower extent compared with metroprolol or bisoprolol alone. Cardiomyocytes cultured in high glucose presented increased
\end{abstract}

Correspondence to: Dr Wenbin Zhang, Key Laboratory of Cardiovascular Intervention and Regenerative Medicine of Zhejiang, Department of Cardiology, Sir Run Run Shaw Hospital, School of Medicine, Zhejiang University, 3 East Qingchun Road, Hangzhou, Zhejiang 310027, P.R. China

E-mail: 3313011@zju.edu.cn

*Contributed equally

Key words: diabetic cardiomyopathy, cardiac hypertrophy, protein kinase $\mathrm{C}$, metoprolol, bisoprolol pulsatile frequency, cellular diameter, surface area, and protein content and synthesis, higher expression of ANP and $\beta$-MHC, and lower $\alpha$-MHC expression. High glucose levels also upregulated the expression and activation of PKC- $\alpha$, PKC $-\beta_{2}$, NF- $\kappa \mathrm{B}, \mathrm{TNF}-\alpha$ and c-fos. Metoprolol and bisoprolol partly reversed the above changes, while combined use of metoprolol or bisoprolol with PKC inhibitor or NF-kB inhibitor further ameliorated the hypertrophic response mentioned above to lower levels compared with using metroprolol or bisoprolol alone. In conclusion, metoprolol and bisoprolol could prevent hypertrophy of cardiomyocytes cultured in high glucose by the inhibition of the total and phospho-PKC- $\alpha$, which could further influence the PKC- $\alpha / \mathrm{NF}-\kappa \mathrm{B} / \mathrm{c}$-fos signaling pathway.

\section{Introduction}

As a common noncommunicable chronic disease, diabetes mellitus (DM) has become a global health issue. It is estimated that the morbidity of DM is expected to rise to 552 million by 2030 (1). Subjected to a relative or absolute deficiency of insulin secretion, patients with DM present numerous complications due to the long-term conditions of hyperglycemia, such as diabetic cardiomyopathy. DM may also cause abnormality in the heart metabolic signaling pathway. These mediators can result in diastolic dysfunction at the early stage of DM and damaged systolic function at the late stage of DM (2).

A number of studies have been performed to explore potential critical signaling pathways in DM (3-5). For example, in the pathogenesis of diabetic cardiomyopathy, the state of chronic hyperglycemia increases the formation of diacylglycerol (DAG), activates protein kinase C (PKC) and accelerates non-enzymatic formation of advanced glycated end products (6). These intracellular changes eventually cause structural and functional alteration of cardiomyocytes.

The PKC family comprises of more than ten different isozymes and was found to be associated with cardiovascular diseases such as cardiac hypertrophy and ischemia-reperfusion injury $(7,8)$. It was reported that PKC inhibition could partly reverse both structural abnormalities and cardiac dysfunction in cardiac hypertrophy (9). PKC- $\alpha$ and PKC- $\beta_{2}$ are two highly expressed PKC isoforms in the heart. Previous studies 
showed that high glucose stimulation could activate PKC- $\alpha$ and PKC $-\beta_{2}$ at the early stage of diabetic cardiomyopathy (10). Such changes of those two isoforms suggested they may act as an important mediator in the pathological progress of diabetic cardiomyopathy (11). However, the exact role of the PKC family and its downstream signaling pathway in diabetic cardiomyopathy remains to be completely elucidated.

$\beta$-receptor blockers ( $\beta$-blockers) are one of the most commonly used medicines for the treatment of cardiovascular diseases, including cardiac hypertrophy, heart failure, arrhythmia and angina $(12,13)$. Use of $\beta$-blockers could effectively improve cardiac function, reverse the remodeling of left-ventricle and enhance the ability of physical exercise-related capacity (14). Although the prognostic benefits of $\beta$-blockers for patients with cardiovascular disease are commonly recognized, they are yet to be elucidated in patients with diabetes, as beta-blockers could delay the development of diabetes by counteracting hypoglycemia symptoms (15). However, $\beta$-blockers can also disrupt glycemic control and lipid metabolism of diabetic patients. In a Glycemic Effects in Diabetes Mellitus: Carvedilil-Metoprolol Comparison in Hypertensives study, patients with hypertension and type 2 DM (T2DM) treated with metaprolol showed a significant increase in hemoglobin $\mathrm{A}_{1 \mathrm{c}}$ levels compared with baseline levels (16). In another study, insulin-stimulated endothelial function in diabetic patients was significantly decreased following treatment with metaprolol (17). However, diabetic patients who have developed systolic heart failure (SHF) may still benefit from appropriate $\beta$-blocker therapy. A meta-analysis of large-scale clinical trials has verified that $\beta$-blockers could reduce mortality rates in patients with SHF with DM (18).

Metoprolol and bisoprolol, both $\beta$-antagonists, improve the prognosis of heart failure and prevent the progression of left ventricle remodeling (19). In ischemic or non-ischemic heart failure, both metoprolol and bisoprolol have been reported to reduce cardiac events, attenuate cardiac dysfunction, and reduce mortality $(20,21)$. Therapy with beta-blockers, such as bisoprolol, has a favorable effect in clinical outcomes of reducing mortality and morbidity of heart failure patients with new-onset DM, either with heart failure with preserved or reduced ejection fraction (22). However, how metoprolol and bisoprolol attenuate left ventricle remodeling or dysfunction associated with diabetic cardiomyopathy remains to be determined.

In the present study, PKC and its downstream $\mathrm{PKC} / \mathrm{NF}-\kappa \mathrm{B} /$ c-fos signaling pathway was hypothesized to be critical for the development of cardiac hypertrophy related to diabetic cardiomyopathy. Moreover, the current study also aimed to determine whether metoprolol and bisoprolol could attenuate cardiac hypertrophy induced by hyperglycemia and elucidate the underlying mechanism of this process.

\section{Materials and methods}

Experimental animals. Cardiomyocytes of each experiment were derived from 1 to 3-day-old neonatal Sprague-Dawley rats (total number of rats, 30; weight, 4-6 g; male rats, 15; female rats, 15), provided by the Laboratory Animal Center of Zhejiang University. Animals were housed in a temperature of $22-26^{\circ} \mathrm{C}$ and a humidity of $50-65 \%$ controlled environment with a 12-h light-dark cycle. The rats had free access to water and food. Procedures in the current study were all conducted according to the guidelines for animal care (23) and approved by the Ethics Committee of Zhejiang University.

Reagents, chemicals and drugs. DMEM, FBS and $0.25 \%$ trypsin were obtained from Gibco; Thermo Fisher Scientific, Inc.; type II collagenase, glucose and $\left[{ }^{3} \mathrm{H}\right]$-leucine were provided by Sigma-Aldrich; Merck KGaA. Ro-31-8220 and BAY11-7082 were obtained from Selleck Chemcicals; metoprolol and bisoprolol were obtained from AstraZeneca. Primary antibodies for detection of PKC- $\alpha$ (cat. no. 2056), p-PKC- $\beta_{2}$ (cat. no. 9371), NF- $\kappa \mathrm{B}$ p65 (cat. no. 8242), p-NF-кB (cat. no. 3033), Histone H3 (cat. no. 9717) and c-fos (cat.no. 2250) were purchased from Cell Signaling Technology. PKC- $\beta_{2}$ (cat. no. sc-210) and p-PKC- $\alpha$ (cat. no. sc-12356) were purchased from Santa Cruz Biotechnology. $\beta$-actin primary antibody (cat. no. 70-ab010-100) and horseradish peroxidase-linked goat anti-rabbit secondary antibodies (cat. no. 70-GAM0072) were purchased from MultiSciences Biotech Co., Ltd. Primers were designed according to our previous study (11) and synthesized by TSINGKE. TRIzon reagent (cat. no. CW0580) for extracting total RNA and UltraSYBR Mixture (cat. no. CW0957) for reverse transcription-quantitative PCR (RT-qPCR) assays were purchased from CWBIO Biosciences. PrimeScript RT-PCR kit was purchased from Takara Bio, Inc.

Isolation and culture of neonatal rat cardiomyocytes. Cardiomyocytes were obtained and cultured as follows. Neonatal Sprague-Dawley rats were sacrificed and hearts were dissected. A diluted solution made up of $0.125 \%$ trypsin and $0.1 \%$ type II collagenase was used to digest the ventricular tissues for $8 \mathrm{~min}$ at $37^{\circ} \mathrm{C}$. Following each digestion, the supernatant was collected and added to DMEM with $10 \%$ FBS. The step was repeated six to eight times until the ventricles were completely digested. The collected mixture was then centrifuged at $55.9 \times \mathrm{g}$ for $5 \mathrm{~min}$ at room temperature. The supernatant was discarded and cells were resuspended in ACK Lysis Buffer (Beijing Solarbio Science and Technology Co., Ltd.) for $2 \mathrm{~min}$. The cells were centrifuged as described above once again, and the collected cells were resuspended in DMEM with 10\% FBS. Differential adhesion method was used for separating cardiomyocytes from myofibroblasts. Cardiomyocytes were diluted to (3-5) $\times 10^{5} / \mathrm{ml}$ in DMEM with $10 \%$ FBS and cultured in six-well plates in a humidified atmosphere with $5 \% \mathrm{CO}_{2}$ at $37^{\circ} \mathrm{C}$. Culture medium was replaced with serum-free DMEM after $48 \mathrm{~h}$.

Treatment groups. After the first $48 \mathrm{~h}$, cardiomyocytes were cultured in serum-free DMEM with different concentrations of glucose and drugs for another 48 , or $72 \mathrm{~h}$ for the $\left[{ }^{3} \mathrm{H}\right]$-leucine incorporation measurements at $37^{\circ} \mathrm{C}$ with humidified $5 \% \mathrm{CO}_{2}$ as follows: Low glucose (LG; $5.5 \mathrm{mM})$, high glucose $(\mathrm{HG}$; $25.5 \mathrm{mM}), \mathrm{HG}+$ metoprolol $(0.5$ or $10 \mu \mathrm{M}), \mathrm{HG}+$ bisoprolol (50 or $200 \mathrm{nM}), \mathrm{HG}+\mathrm{PKC}$ inhibitor Ro-31-8220 (50 nM) and $\mathrm{HG}+\mathrm{NF}-\kappa \mathrm{B}$ inhibitor BAY11-7082 $(5 \mu \mathrm{M})$. A higher dose of metoprolol or bisoprolol was used in combination with PKC inhibitor (Ro-31-8220) or NF- $\mathrm{KB}$ inhibitor (BAY11-7082) to determine whether the hypertrophic response could be 
attenuated to a lower extent compared with metoprolol or bisoprolol treatment alone. Cells were cultured in serum-free DMEM in the following conditions: $\mathrm{HG}+$ metoprolol $(10 \mu \mathrm{mol} / \mathrm{l})+\mathrm{Ro}-31-8220(50 \mathrm{nmol} / \mathrm{l}), \mathrm{HG}+$ metoprolol $(10 \mu \mathrm{mol} / \mathrm{l})+\mathrm{BAY} 11-7082(5 \mu \mathrm{mol} / \mathrm{l}), \mathrm{HG}+$ bisoprolol $(200 \mathrm{nmol} / \mathrm{l})+$ Ro-31-8220 (50 nmol/l) and $\mathrm{HG}+$ bisoprolol $(200 \mathrm{nmol} / \mathrm{l})+\mathrm{BAY} 11-7082(5 \mu \mathrm{mol} / \mathrm{l})$.

Determination of cellular pulsatile frequency. Individual cellular pulsatile frequency of cardiomyocytes was determined using an inverted light microscope. The inverted microscope and 24-well plates were briefly placed in a homoiothermic air convection assembly, which was fully covered by convection air at $37^{\circ} \mathrm{C}$. Five random fields from each group were selected and 20 individual cardiomyocytes of each field were counted for the pulsatile frequency at x400 magnification.

Measurement of cellular diameter. Cardiomyocytes on glass coverslips were washed with warm PBS twice, fixed with $4 \%$ paraformaldehyde for $10 \mathrm{~min}$ at room temperature and permeabilized with $0.5 \%$ Triton- 100 for $5 \mathrm{~min}$ at room temperature. After washing, cells were incubated with $100 \mathrm{nM}$ rhodamine-phalloidin (Beijing Solarbio Science and Technology Co., Ltd.) for $30 \mathrm{~min}$ at room temperature. Cells were then stained with DAPI (Beijing Solarbio Science and Technology Co., Ltd.) for $30 \mathrm{sec}$ at room temperature. Images of five randomly selected fields of view were captured for each group and used to measure the cellular diameters of cardiomyocytes using a fluorescent microscope at x400 magnification.

Determination of cell protein content. Cardiomyocytes were washed with Hanks' balanced salt solution (HBSS) three times before being lysed with $1 \%$ SDS. Protein content measurement was then carried out in accordance with the Lowry method (24). A standard protein solution was utilized to prepare a standard curve for the final estimation of protein content. The absorbance of the final solution was then measured at a wavelength of $750 \mathrm{~nm}$.

Incorporation of $\left[{ }^{3} \mathrm{H}\right]$-leucine. To measure newly synthesized protein of cardiomyocytes (25), [ $\left.{ }^{3} \mathrm{H}\right]$-leucine incorporation method was conducted as previously described by Luo et al (26). Firstly, $1 \mu \mathrm{Ci}\left[{ }^{3} \mathrm{H}\right]$-leucine was added to cell culture medium with corresponding levels of glucose for cardiomyocytes treatment. $\beta$-blockers and inhibitors were then co-incubated with the cells for $72 \mathrm{~h}$. Following incubation, cells were quickly washed with cold HBSS three times. A total of $1 \mathrm{ml} 1 \%$ SDS was added to each well to lyse cells and the lysates were collected. Subsequently, $1 \mathrm{ml} \mathrm{5 \%}$ trichloroacetic acid was added to the lysates at $4^{\circ} \mathrm{C}$ for $1 \mathrm{~h}$ before the lysates were precipitated and transferred to fiberglass filters. Finally, lysates were washed with HBSS before the precipitates were dried and moved to scintillation fluid. Radioactivity was detected and expressed as cpm/well by liquid scintillation counting.

Nucleus extraction. To detect the translocation of $\mathrm{NF}-\kappa \mathrm{B}$ and $\mathrm{p}-\mathrm{NF}-\kappa \mathrm{B}$ in the nucleus by the glucose stimulation, nucleus extraction was conducted using Nuclear Extraction kit (cat. no. SN0020) according to the manufacture's protocol
(Beijing Solarbio Life Science \& Technology Co., Ltd.). Cells in the cultured plates with a density of $5 \times 10^{5} / \mathrm{ml}$ were firstly digested with EDTA buffer and washed with PBS. Those cells were centrifuged at the speed of $800 \mathrm{x}$ g for $5 \mathrm{~min}$ at $4^{\circ} \mathrm{C}$ and resuspended with $1 \mathrm{ml}$ cold lysis buffer with PMSF and $50 \mu \mathrm{l}$ Reagent A provided by the kit. Then, the $1.05 \mathrm{ml}$ cell suspension was transferred to a small glass homogenizer, and the cells were grinded 20-30 times in an ice bath. Then, the cell homogenates were centrifuged at the speed of $700 \mathrm{xg}$ at $4^{\circ} \mathrm{C}$ for $5 \mathrm{~min}$ to collect the sediments. After resuspension with $0.5 \mathrm{ml}$ cold lysis buffer, the same amount of medium buffer were mixed and centrifuged at the speed of $700 \times \mathrm{g}$ at $4^{\circ} \mathrm{C}$ for $5 \mathrm{~min}$. The nucleus was resuspended with lysis buffer and centrifuged at the speed of $1,000 \mathrm{xg}$ at $4^{\circ} \mathrm{C}$ for $10 \mathrm{~min}$. The final sediments were resuspended by the store buffer provided by the kit.

$R T$-qPCR. Measurement of atrial natriuretic peptide (ANP), $\alpha$-myosin heavy chain $(\alpha-\mathrm{MHC})$ and $\beta$-myosin heavy chain $(\beta$-MHC) and tumor necrosis factor- $\alpha$ (TNF- $\alpha)$ mRNA transcripts was performed using RT-qPCR. Total RNA from cardiomyocytes was extracted using TRIzon reagent and reverse transcribed into cDNA using a PrimeScript RT-PCR kit (Takara Bio, Inc.) according to the manufacturer's instructions. mRNA quantification was conducted using Nanodrop 2000 (Applied Biosystems; Thermo Fisher Scientific, Inc.) (27). The thermcycling condition used were as follows: Initial denaturation at $95^{\circ} \mathrm{C}$ for $10 \mathrm{~min}$; followed by 40 cycles, each cycle included denaturation at $95^{\circ} \mathrm{C}$ for $15 \mathrm{sec}$ and an extension at $60^{\circ} \mathrm{C}$ for $1 \mathrm{~min}$. RT-qPCR was performed with UltraSYBR Mixture on the Viia 7 system (Applied Biosystems; Thermo Fisher Scientific, Inc.) following the manufacturer's instructions. The primers used in the current study are listed in Table I.

RT-qPCR and Southern blot. The mRNA expresssion level of TNF- $\alpha$ was measured by RT-qPCR and Southern blot. RT-qPCR was performed to convert the mRNA into cDNA as described above, followed by PCR using the primers listed in Table I to amplify the target fragments. The resulting products were then separated on $1.2 \%$ agarose gel and stained with $1 \mu \mathrm{g} / \mathrm{ml}$ ethidium bromide for $30 \mathrm{~min}$ at room temperature. The bands were then exposed and quantified using Gel DOC XR image system (Bio-Rad Laboratories, Inc.). The intensity of the TNF- $\alpha$ band was normalized by GAPDH. Densitometry was analyzed using ImageJ software (version 2.1.4.7; National Institutes of Health).

Western blot analysis of cultured cardiomyocytes. Cells were washed with cold PBS twice and lysed with RIPA buffer and PMSF (Beijing Solarbio Science and Technology Co., Ltd.; 100:1) for $15 \mathrm{~min}$. Lysates were centrifuged at 8,049.6 x $\mathrm{g}$ for $15 \mathrm{~min}$ at $4^{\circ} \mathrm{C}$. After quantification by bicinchoninic acid assay, the collected supernatant was added to $5 \mathrm{X}$ loading buffer $(4: 1)$ and incubated at $100^{\circ} \mathrm{C}$ for $5 \mathrm{~min}$. Protein separation was conducted using 10\% SDS-PAGE gels. A total of $20 \mu \mathrm{g}$ of protein from each group and $5 \mu \mathrm{l}$ of marker were loaded into each lane. The separated protein was then transferred to PVDF membranes and blocked with $5 \%$ non-fat milk for $1 \mathrm{~h}$ at room temperature. The membranes were incubated with primary 
Table I. List of primers used for reverse transcription-quantitative PCR.

Primer sequence 5'-3'

\begin{tabular}{lll}
\cline { 2 - 3 } Gene & \multicolumn{1}{c}{ Forward } & Reverse \\
\hline ANP & GCTCGAGCAGATCGCAAAAG & CACCACCTCTCAGTGGCAAT \\
$\alpha-\mathrm{MHC}$ & GCCGAGTCCCAGGTCAACA & TATTGGCCACAGCGAGGGTCT \\
$\beta-\mathrm{MHC}$ & CACCCGCGAGTACAACCTTC & CCCATACCCACCATCACACC \\
TNF- $\alpha$ & GAACAACCCTACGAGCACCT & GGGTAGTTTGGCTGGGATAA \\
GAPDH & ACCCACTTCTCCACCTTTGAC & TGTTGCTGTAGCCAAATTCG
\end{tabular}

ANP, atrial natriuretic peptide; MHC, myosin heavy chain.

Table II. Effects of metoprolol, bisoprolol, Ro-31-8220 and BAY11-7082 on pulsatile frequency and cellular diameter of cardiomyocytes cultured in high glucose.

\begin{tabular}{lcc}
\hline Treatment & Pulsatile frequency $(\mathrm{bpm})$ & Diameter $(\mu \mathrm{m})$ \\
\hline Low glucose $(5.5 \mathrm{mmol} / \mathrm{l})$ & $57.63 \pm 1.82$ & $18.50 \pm 0.67$ \\
High glucose $(25.5 \mathrm{mmol} / \mathrm{l})$ & $69.42 \pm 1.66^{\mathrm{a}}$ & $24.81 \pm 0.78^{\mathrm{a}}$ \\
High glucose + metoprolol $(0.5 \mu \mathrm{mol} / \mathrm{l})$ & $64.25 \pm 1.64^{\mathrm{b}}$ & $21.82 \pm 0.60^{\mathrm{b}}$ \\
High glucose + metoprolol $(10 \mu \mathrm{mol} / \mathrm{l})$ & $61.74 \pm 2.11^{\mathrm{b}, \mathrm{c}}$ & $20.12 \pm 0.57^{\mathrm{b}, \mathrm{c}}$ \\
High glucose + bisoprolol $(50 \mathrm{nmol} / \mathrm{l})$ & $63.83 \pm 1.65^{\mathrm{b}}$ & $21.54 \pm 0.48^{\mathrm{b}}$ \\
High glucose + bisoprolol $(200 \mathrm{nmol} / \mathrm{l})$ & $61.12 \pm 1.88^{\mathrm{b}, \mathrm{d}}$ & $19.76 \pm 0.6^{\mathrm{b}, \mathrm{d}}$ \\
High glucose + Ro-31-8220 $(50 \mathrm{nmol} / \mathrm{l})$ & $63.90 \pm 1.38^{\mathrm{b}}$ & $19.98 \pm 0.55^{\mathrm{b}}$ \\
High glucose + BAY11-7082 $(5 \mu \mathrm{mol} / \mathrm{l})$ & $62.31 \pm 1.70^{\mathrm{b}}$ & $19.70 \pm 0.62^{\mathrm{b}}$
\end{tabular}

Data are presented as the mean $\pm \mathrm{SD}$ ( $\mathrm{n}=100$ cardiomyocytes for measurement of each group). ${ }^{\mathrm{a}} \mathrm{P}<0.05 \mathrm{vs}$. LG group, ${ }^{\mathrm{b}} \mathrm{P}<0.05 \mathrm{vs}$. HG group, ${ }^{\mathrm{c}} \mathrm{P}<0.05 \mathrm{vs}$. HG group + metoprolol $(0.5 \mu \mathrm{mol} / \mathrm{l})$ group, ${ }^{\mathrm{d}} \mathrm{P}<0.05 \mathrm{vs} . \mathrm{HG}+$ bisoprolol $(50 \mathrm{nmol} / \mathrm{l})$ group.

antibodies and $5 \%$ BSA $(1: 1,000)$ overnight at $4^{\circ} \mathrm{C}$. Following primary antibody incubation, membranes were incubated with secondary antibodies $(1: 5,000)$ for $2 \mathrm{~h}$ at room temperature. Protein bands were visualized using the HRP-ECL kit (Bio-Rad Laboratores, Inc.), and optical density was measured using the Amersham Imager 600 System (GE Healthcare Life Sciences). The intensity of bands were normalized to $\beta$-actin. Densitometry of western blot bands was analyzed using ImageJ software (version 2.1.4.7; National Institutes of Health).

Statistical analysis. All experimental data are presented as the mean \pm SD for at least three individual experiments. Statistical analysis of multiple comparisons was performed by one-way ANOVA followed by a Tukey's post-hoc test using GraphPad Prism software (Version 8.0; GraphPad Software, Inc.). $\mathrm{P}<0.05$ indicated statistically significant differences.

\section{Results}

Metoprolol and bisoprolol decrease the pulsatile frequency, cellular diameter and cell surface area of HG-treated cardiomyocytes. Cardiomyocytes treated with HG showed increased pulsatile frequency and cellular diameter compared with LG-treated samples $(69.42 \pm 1.66$ vs. $57.63 \pm 1.82 \mathrm{bpm}$, $\mathrm{P}<0.05$; and $24.81 \pm 0.78$ vs. $18.50 \pm 0.67 \mu \mathrm{m}, \mathrm{P}<0.05)$. The cell surface area of HG-treated cardiomyocytes was also increased by 2.6-fold compared with the LG-treated cardiomyocytes. After adding metoprolol, bisoprolol, Ro-31-8220 and BAY11-7082, the pulsatile frequency, cellular diameter and cell surface area of cardiomyocytes decreased significantly compared with the HG group, as shown in Table II and Fig. 1A.

Metoprolol and bisoprolol decrease the total protein content and $\left[{ }^{3} \mathrm{H}\right]$-leucine incorporation of $\mathrm{HG}$-treated cardiomyocytes. Cardiomyocytes treated with HG presented increased total protein content and $\left[{ }^{3} \mathrm{H}\right]$-leucine incorporation compared with LG-treated cardiomyocytes (57.21 \pm 5.29 vs. $31.22 \pm 2.30 \mu \mathrm{g} /$ well, $\mathrm{P}<0.05$; and $1,510.64 \pm 82.31$ vs. $1,033.21 \pm 60.33 \mathrm{cpm} /$ well, $\mathrm{P}<0.05)$. Following addition of metoprolol, bisoprolol, Ro-31-8220 and BAY11-7082, total protein content and $\left[{ }^{3} \mathrm{H}\right]$-leucine incorporation of cardiomyocytes was significantly reduced compared with the HG group $(\mathrm{P}<0.05)$, as shown in Table III.

Metoprolol and bisoprolol regulate ANP, $\alpha-M H C$ and $\beta-M H C$ $m R N A$ levels of $H G$-treated cardiomyocytes. Cardiomyocytes treated with HG showed increased mRNA levels of ANP and $\beta$-MHC and decreased mRNA levels of $\alpha$-MHC compared with LG-treated cardiomyocytes (all $\mathrm{P}<0.05$ ). Following addition of metoprolol, bisoprolol, Ro-31-8220 and BAY11-7082, mRNA 
Table III. Effects of metoprolol, bisoprolol, Ro-31-8220 and BAY11-7082 on total protein content and [ $\left.{ }^{3} \mathrm{H}\right]$-leucine incorporation of cardiomyocytes cultured in high glucose.

Treatment

Low glucose $(5.5 \mathrm{mmol} / \mathrm{l})$

High glucose $(25.5 \mathrm{mmol} / \mathrm{l})$

High glucose + metoprolol $(0.5 \mu \mathrm{mol} / \mathrm{l})$

High glucose + metoprolol $(10 \mu \mathrm{mol} / \mathrm{l})$

High glucose + bisoprolol $(50 \mathrm{nmol} / \mathrm{l})$

High glucose + bisoprolol $(200 \mathrm{nmol} / \mathrm{l})$

High glucose + Ro-31-8220 (50 nmol/l)

High glucose + BAY11-7082 (5 $\mu \mathrm{mol} / \mathrm{l})$
Protein $(\mu \mathrm{g} /$ well $)$

$\left[{ }^{3} \mathrm{H}\right]$-leucine incorporation (cpm/well)
$1,033.21 \pm 60.33$
$1,510.64 \pm 82.31^{\mathrm{a}}$
$1,318.15 \pm 63.91^{\mathrm{b}}$
$1,152.82 \pm 87.84^{\mathrm{b}, \mathrm{c}}$
$1,140.53 \pm 76.26^{\mathrm{b}}$
$1,130.29 \pm 73.05^{\mathrm{b}}$
$1,330.27 \pm 74.84^{\mathrm{b}}$
$1,158.76 \pm 87.43^{\mathrm{b}}$

Data are presented as the mean $\pm \mathrm{SD}$ ( $\mathrm{n}=100$ cardiomyocytes for measurement of each group). ${ }^{\mathrm{a}} \mathrm{P}<0.05$ vs. $\mathrm{LG}$ group, ${ }^{\mathrm{b}} \mathrm{P}<0.05$ vs. $\mathrm{HG}$ group, ${ }^{\mathrm{c}} \mathrm{P}<0.05$ vs. HG group + metoprolol $(0.5 \mu \mathrm{mol} / \mathrm{l})$ group.
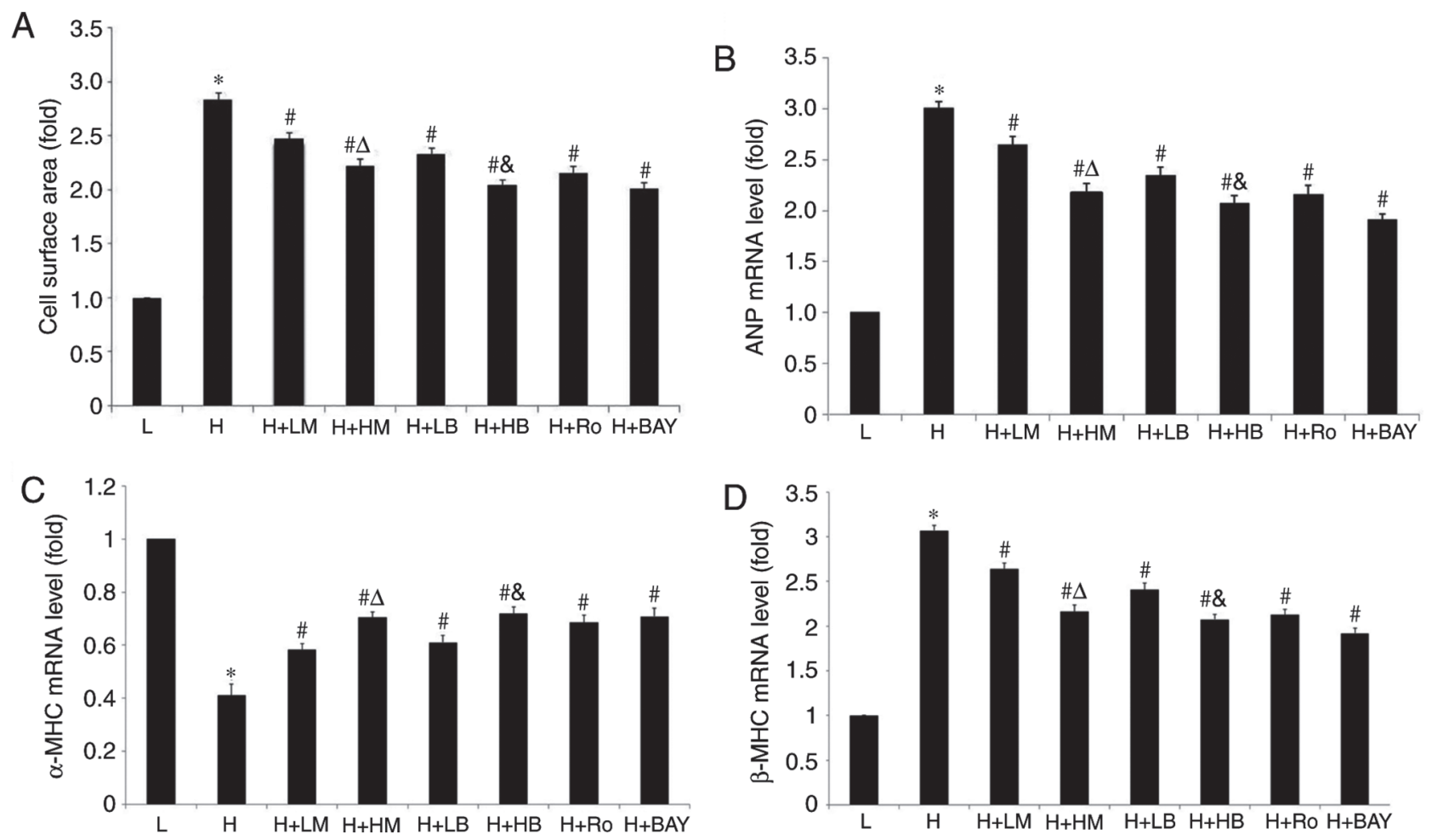

Figure 1. Metoprolol and bisoprolol decrease cell surface area and ANP and $\beta$-MHC mRNA levels and increase $\alpha$-MHC mRNA levels of cardiomyocytes cultured in high glucose. (A) Cell surface area. mRNA expression levels of (B) ANP, (C) $\alpha$-MHC and (D) $\beta$-MHC. $\mathrm{n}=100$ cardiomyocytes for measurement of each group. ${ }^{*} \mathrm{P}<0.05$ vs. $\mathrm{L}$ group, ${ }^{\#} \mathrm{P}<0.05$ vs. $\mathrm{H}$ group, ${ }^{\wedge} \mathrm{P}<0.05$ vs. $\mathrm{H}+\mathrm{LM}$ group, ${ }^{\circledR} \mathrm{P}<0.05$ vs. $\mathrm{H}+\mathrm{LB}$ group. $\mathrm{L}$, low glucose; $\mathrm{H}$, high glucose; LM, low metoprolol dose; HM, high metoprolol dose; LB, low bisoprolol dose; HB, high bisoprolol dose; Ro, Ro-31-8220; BAY, BAY11-7082; ANP, atrial natriuretic peptide; MHC, myosin heavy chain.

expression levels of ANP and $\beta$-MHC in cardiomyocytes were significantly reduced compared with HG-treated samples $(\mathrm{P}<0.05)$. Meanwhile, $\alpha-\mathrm{MHC}$ mRNA levels of cardiomyocytes following treatment with of metoprolol, bisoprolol, Ro-31-8220 and BAY11-7082 were upregulated compared with HG-treated samples (all $\mathrm{P}<0.05$ ), as shown in Fig. 1B-D.

Metoprolol and bisoprolol attenuate the expression and activity of PKC- $\alpha$ and PKC- $\beta_{2}$ in HG-treated cardiomyocytes. Cardiomyocytes treated with $\mathrm{HG}$ showed increased expression and activity of PKC- $\alpha$ and PKC $\beta_{2}$, reflected by the increased expression of PKC- $\alpha$, p-PKC- $\alpha$, PKC- $\beta_{2}$, p-PKC- $\beta_{2}$, as well as the ratios of $\mathrm{p}-\mathrm{PKC}-\alpha / \mathrm{PKC}-\alpha$ and $\mathrm{p}-\mathrm{PKC}-\beta_{2} / \mathrm{PKC}-\beta_{2}$, compared with LG-treated samples $(\mathrm{P}<0.05)$. Following addition of Ro-31-8220 or either dose of metoprolol and bisoprolol, the expression levels of PKC- $\alpha$ and p-PKC- $\alpha$ were significantly decreased compared with HG-treated samples. In addition, the ratio of $\mathrm{p}-\mathrm{PKC}-\alpha / \mathrm{PKC}-\alpha$ was decreased in the Ro-31-8220 group. However, only high doses of metoprolol and bisoprolol could significantly attenute the 


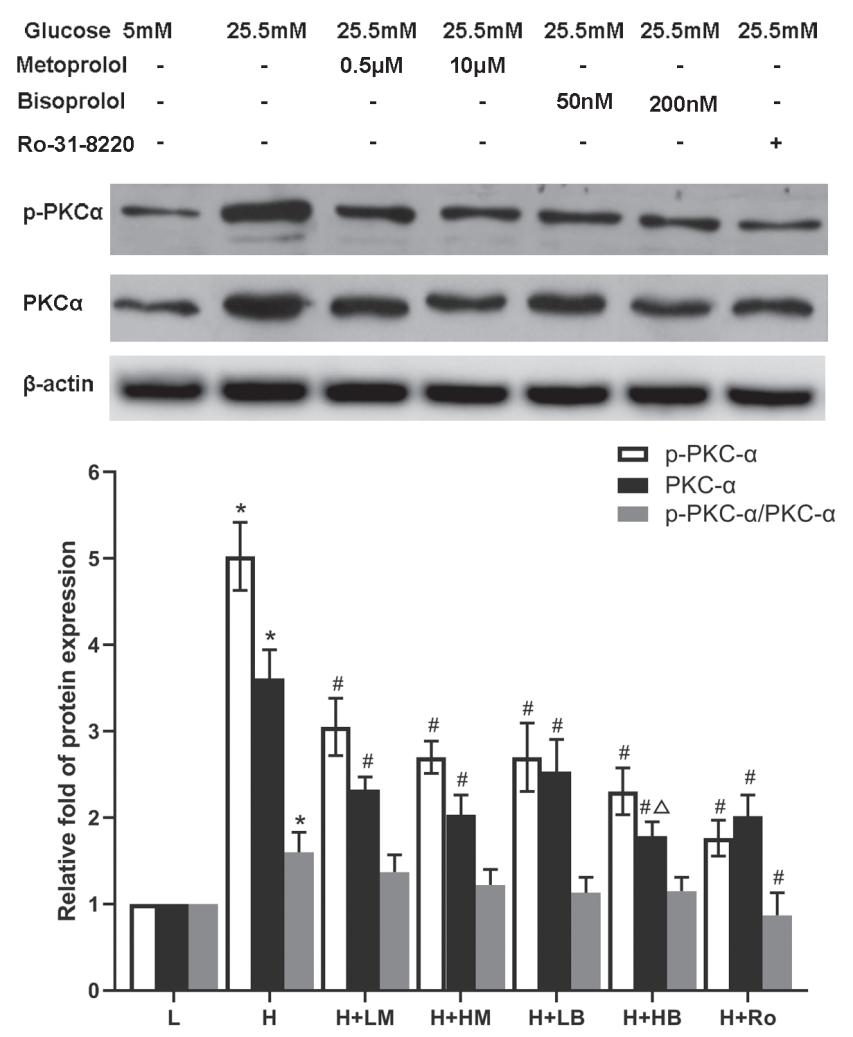

Figure 2. High doses of metoprolol and bisoprolol decreases the expression and activity of PKC- $\alpha$ in cardiomyocytes cultured in high glucose. p-PKC- $\alpha$ and total PKC $\alpha$ protein levels were detected in cells. $\mathrm{n}=4-5$. ${ }^{*} \mathrm{P}<0.05$ vs. $\mathrm{L}$ group, ${ }^{\#} \mathrm{P}<0.05$ vs. $\mathrm{H}$ group, ${ }^{\Delta} \mathrm{P}<0.05$ vs. corresponding low dose group of metoprolol or bisoprolol. L, low glucose; H, high glucose; LM, low metoprolol dose; HM, high metoprolol dose; LB, low bisoprolol dose; HB, high bisoprolol dose; Ro, Ro-31-8220.

increased PKC $-\beta_{2}$ and p-PKC- $\beta_{2}$ protein levels, and the ratio of $\mathrm{p}-\mathrm{PKC}-\beta_{2} / \mathrm{PKC}-\beta_{2}$, except for the PKC- $\beta_{2}$ level treated by high dose of bisoprolol, compared with $\mathrm{HG}$-treated samples $(\mathrm{P}<0.05$; Figs. 2 and 3$)$.

Metoprolol and bisoprolol reduce the expression of phospho-NF- $\kappa B, N F-\kappa B, T N F-\alpha$ and $c$-fos in HG-treated cardiomyocytes. The relative expression of $\mathrm{p}-\mathrm{NF}-\kappa \mathrm{B}, \mathrm{NF}-\kappa \mathrm{B}$, TNF- $\alpha$ and c-fos significantly increased in cardiomyocytes treated with $\mathrm{HG}$ compared with $\mathrm{LG}$-treated samples $(\mathrm{P}<0.05)$. In addition, the ratio of $\mathrm{p}-\mathrm{NF}-\kappa \mathrm{B} / \mathrm{NF}-\kappa \mathrm{B}$ was also increased. Following addition of metoprolol, bisoprolol, Ro-31-8220 and BAY11-7082, the relative expression of $\mathrm{NF}-\kappa \mathrm{B}$ was significantly reduced in those groups compared with HG-treated samples. However, only the high metoprolol dose group, Ro-31-8220 group and BAY11-7082 group decreased the expression level of $p-N F-\kappa B$. The ratio of $p-N F-\kappa B / N F-\kappa B$ was not significantly decreased following these treatments. Treatments of metoprolol, bisoprolol, Ro-31-8220 and BAY11-7082 reduced the mRNA expression levels of TNF- $\alpha$ and protein expression levels of c-fos compared with HG-treated samples $(\mathrm{P}<0.05$; Figs. 4-6). In addition, high dose of bisoprolol further suppressed the mRNA expression levels of TNF- $\alpha$ and protein expression levels of c-fos compared with the low bisoprolol dose group. A similar dose-dependent suppressive effect was also found in high metoprolol dose group on the expression of c-fos protein levels.

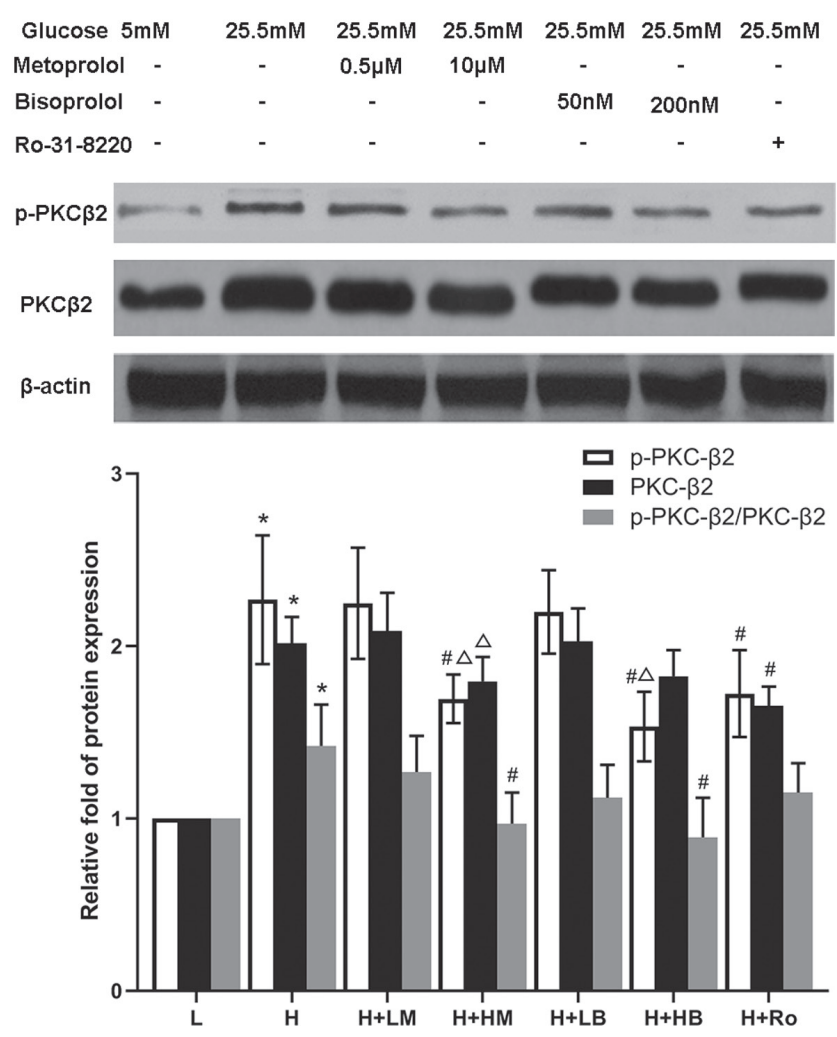

Figure 3. High dose of metoprolol decrease the expression and activity of PKC $-\beta_{2}$ and high dose of bisoprolol decrease the activation of PKC- $\beta_{2}$ in cardiomyocytes cultured in high glucose. $\mathrm{p}-\mathrm{PKC}-\beta$ and total $\mathrm{PKC} \beta$ protein levels were detected in cells. $\mathrm{n}=4-5$. ${ }^{*} \mathrm{P}<0.05$ vs. $\mathrm{L}$ group, ${ }^{\#} \mathrm{P}<0.05$ vs. $\mathrm{H}$ group, ${ }^{\wedge} \mathrm{P}<0.05$ vs. corresponding low dose group of metoprolol or bisoprolol. L, low glucose; H, high glucose; LM, low metoprolol dose; HM, high metoprolol dose; LB, low bisoprolol dose; HB, high bisoprolol dose; Ro, Ro-31-8220.

Combined use of PKC inhibitor, $N F-\kappa B$ inhibitor with metoprolol or bisoprolol further decreases the pulsatile frequency, cellular diameter, cell surface area and regulates ANP, $\alpha-M H C$ and $\beta$-MHC mRNA levels of HG-treated cardiomyocytes. Metoprolol reduced the pulsatile frequency, cellular diameter and cell surface area of cardiomyocytes treated with HG (Table IV; Fig. 7A). The mRNA levels of ANP and $\beta$-MHC of cardiomyocytes were significantly reduced, while $\alpha$-MHC mRNA levels of cardiomyocytes showed a significant increase compared with HG-treated samples (Fig. 7B-D). Combined use of Ro-31-8220 or BAY11-7082 with metoprolol further decreased the pulsatile frequency, cellular diameter and cell surface area of cardiomyocytes treated with HG (Table IV; Figs. 7A and 8), as well as ANP and $\beta$-MHC mRNA expression levels (Fig. 7B and D) compared with the HG-treated samples. In addition, increased $\alpha$-MHC mRNA expression levels were also observed in these treatment groups compared with the HG-treated samples. Similar results were observed when bisoprolol was used in combination with Ro-31-8220 or BAY11-7082 ( $\mathrm{P}<0.05$; Table IV; Fig. 7).

Combined use of PKC inhibitor and $N F-\kappa B$ inhibitor with metoprolol or bisoprolol further decreases total protein content and $\left[{ }^{3} \mathrm{H}\right]$-leucine incorporation of $\mathrm{HG}$-treated cardiomyocytes. In the HG-treated cardiomyocytes, the protein content and $\left[{ }^{3} \mathrm{H}\right]$-leucine incorporation were significantly upregulated compared with LG-treated samples. The present 

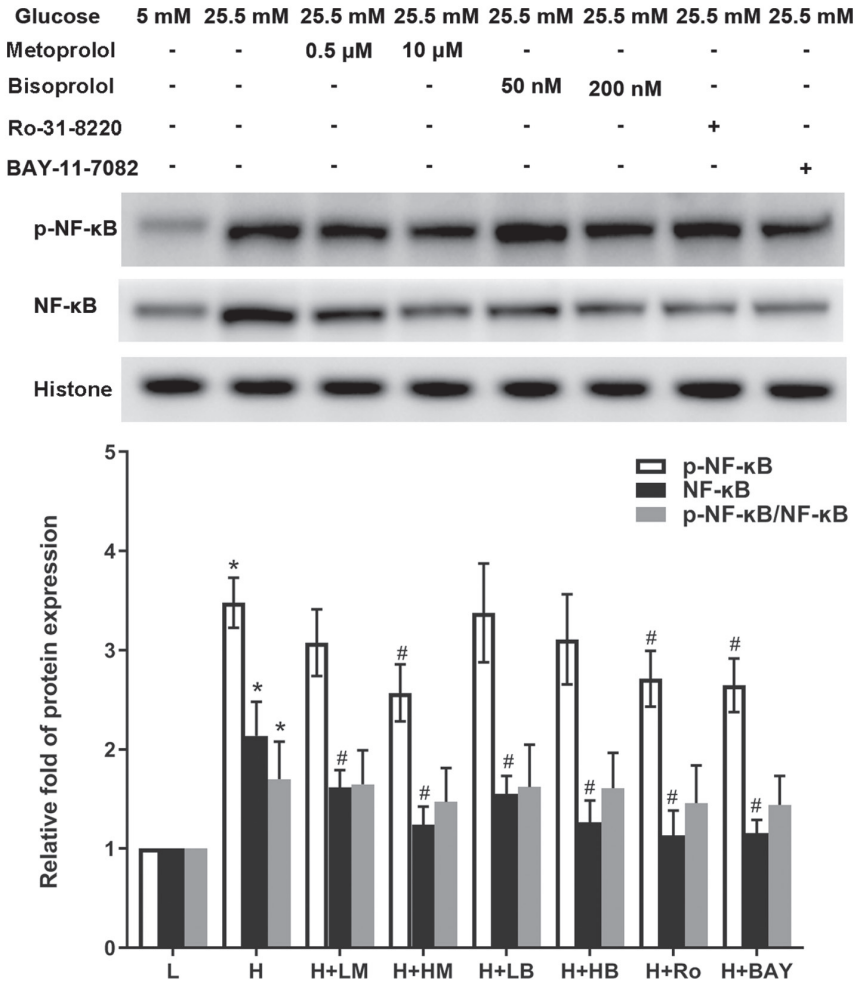

Figure 4. Effects of metoprolol, bisoprolol, PKC inhibitor Ro-31-8220 and $\mathrm{NF}-\kappa \mathrm{B}$ inhibitor BAY11-7082 on the expression and activity of NF- $\kappa \mathrm{B}$ in cardiomyocytes cultured in high glucose. Cardiomyocytes cultured in HG showed higher expression and activity of NF- $\kappa \mathrm{B}$ compared with LG-cultured cardiomyocytes. $\mathrm{n}=4-5$. ${ }^{*} \mathrm{P}<0.05$ vs. $\mathrm{L}$ group, ${ }^{\#} \mathrm{P}<0.05$ vs. $\mathrm{H}$ group, $\mathrm{L}$, low glucose; H, high glucose; LM, low metoprolol dose; HM, high metoprolo dose; LB, low bisoprolol dose; HB, high bisoprolol dose; Ro, Ro-31-8220; BAY, BAY11-7082.

$\begin{array}{lcccccccc}\text { Glucose } & 5 \mathrm{mM} & 25.5 \mathrm{mM} & 25.5 \mathrm{mM} & 25.5 \mathrm{mM} & 25.5 \mathrm{mM} & 25.5 \mathrm{mM} & 25.5 \mathrm{mM} & 25.5 \mathrm{mM} \\ \text { Metoprolol } & - & - & 0.5 \mu \mathrm{M} & 10 \mu \mathrm{M} & - & - & - & - \\ \text { Bisoprolol } & - & - & - & - & 50 \mathrm{nM} & 200 \mathrm{nM} & - & - \\ \text { Ro-31-8220 } & - & - & - & - & - & - & + & - \\ \text { BAY-11-7082 } & - & - & - & - & - & - & - & +\end{array}$
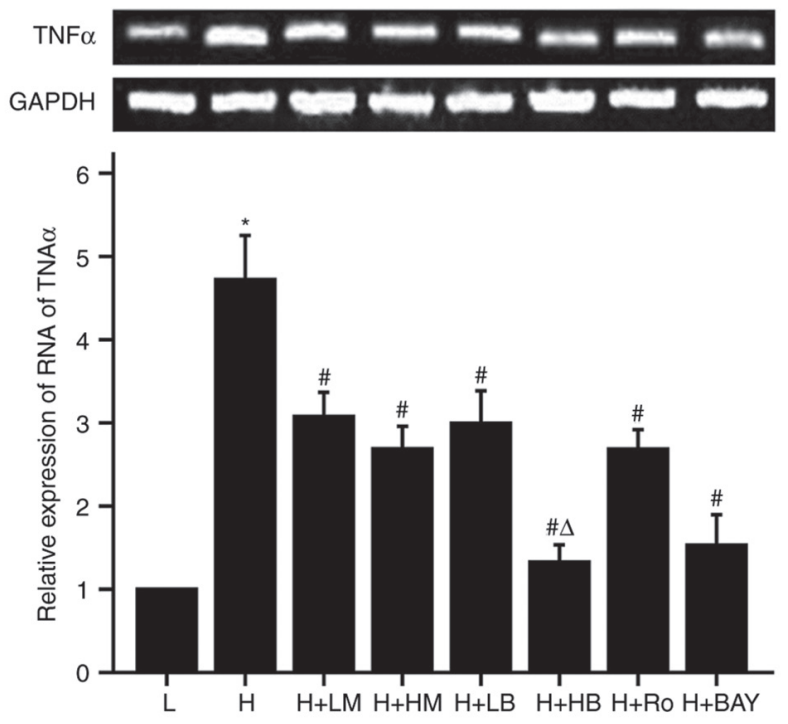

Figure 5. Effects of metoprolol, bisoprolol, PKC inhibitor Ro-31-8220 and $\mathrm{NF}-\kappa \mathrm{B}$ inhibitor BAY11-7082 on TNF- $\alpha$ expression in cardiomyocytes cultured in HG. $\mathrm{n}=4-5$. ${ }^{*} \mathrm{P}<0.05$ vs. $\mathrm{L}$ group, ${ }^{\sharp} \mathrm{P}<0.05$ vs. $\mathrm{H}$ group, ${ }^{\Delta} \mathrm{P}<0.05$ vs. $\mathrm{HG}+\mathrm{LB}$ group. L, low glucose; $\mathrm{H}$, high glucose; LM, low metoprolol dose; HM, high metoprolol dose; LB, low bisoprolol dose; HB, high bisoprolol dose; Ro, Ro-31-8220; BAY, BAY11-7082; TNF- $\alpha$, tumor necrosis factor- $\alpha$.
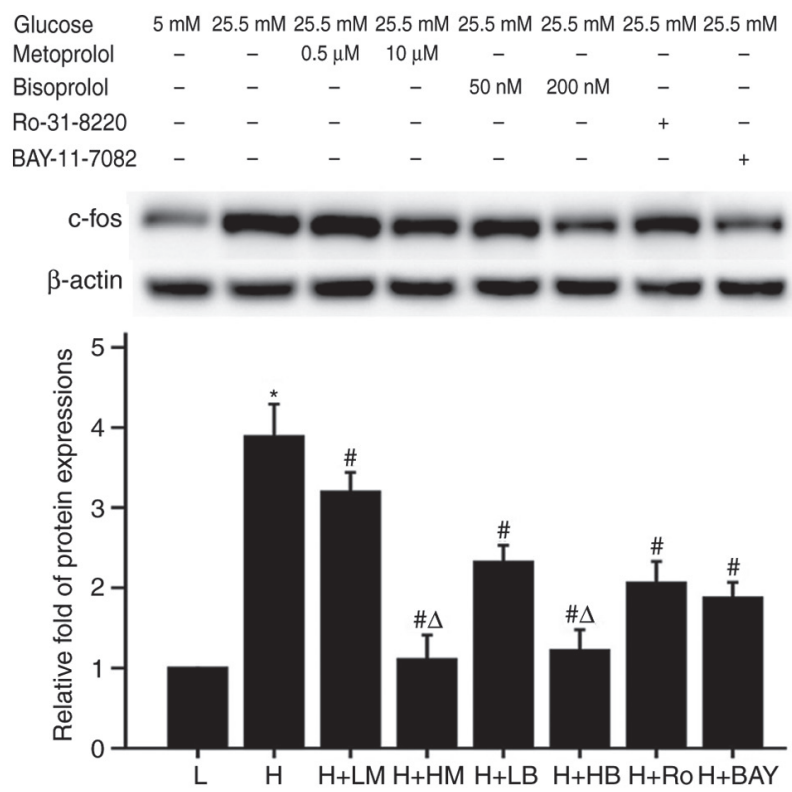

Figure 6. Effects of metoprolol, bisoprolol, PKC inhibitor Ro-31-8220 and NF- $\kappa$ B inhibitor BAY11-7082 on c-fos expression in cardiomyocytes cultured in HG. $\mathrm{n}=4-5$. ${ }^{*} \mathrm{P}<0.05$ vs. $\mathrm{L}$ group, ${ }^{\#} \mathrm{P}<0.05$ vs. $\mathrm{H}$ group, ${ }^{\Delta} \mathrm{P}<0.05$ vs. corresponding low dose group of metoprolol or bisoprolol. L, low glucose; H, high glucose; LM, low metoprolol dose; HM, high metoprolol dose; LB, low bisoprolol dose; HB, high bisoprolol dose; Ro, Ro-31-8220; BAY, BAY11-7082.

results suggested that reatments with metoprolol or bisoprolol could inhibit this upregulation in HG-treated samples. Moreover, when combining the use of the PKC inhibitor and $\mathrm{NF}-\kappa \mathrm{B}$ inhibitor with metoprolol or bisoprolol, the protein content and $\left[{ }^{3} \mathrm{H}\right]$-leucine incorporation could be further downregulated compared with metoprolol or bisoprolol treatment alone $(\mathrm{P}<0.05$; Table $\mathrm{V})$.

\section{Discussion}

Patients with diabetic cardiomyopathy generally display progressive development of impaired systolic and diastolic dysfunction and heart failure (2). However, the exact underlying pathological mechanism remains to be further elucidated. The DAG-PKC signaling pathway plays an important role in the initiation and development of diabetic cardiomyopathy. A number of studies investigated the impact of HG on the structural and functional alterations in cardiac myocytes. The classical phenotype in diabetic cardiomyopathy is characterized by increased pulsatile frequency, myocardial size and protein content and synthesis (28). The present study mainly explored the protective effects of two types of beta-blockers, metoprolol and bisoprolol, on such hypertrophic changes and the associated signaling pathway.

Previous studies found that diabetic rats showed a significantly increased probability of developing cardiac hypertrophy compared with normal rats $(28,29)$, which was regulated by the $\mathrm{PKC} / \mathrm{NF}-\kappa \mathrm{B} / \mathrm{c}$-fos signaling pathway. In addition, another previous study found that overexpression of PKC activated NF- $\kappa \mathrm{B}$ and promoted the expression of $\mathrm{c}-\mathrm{fos}$, resulting in cardiac hypertrophy and decreased contractility of cardiomyocytes, consequently leading to heart failure (30). However, upon treatment with pharmacological 

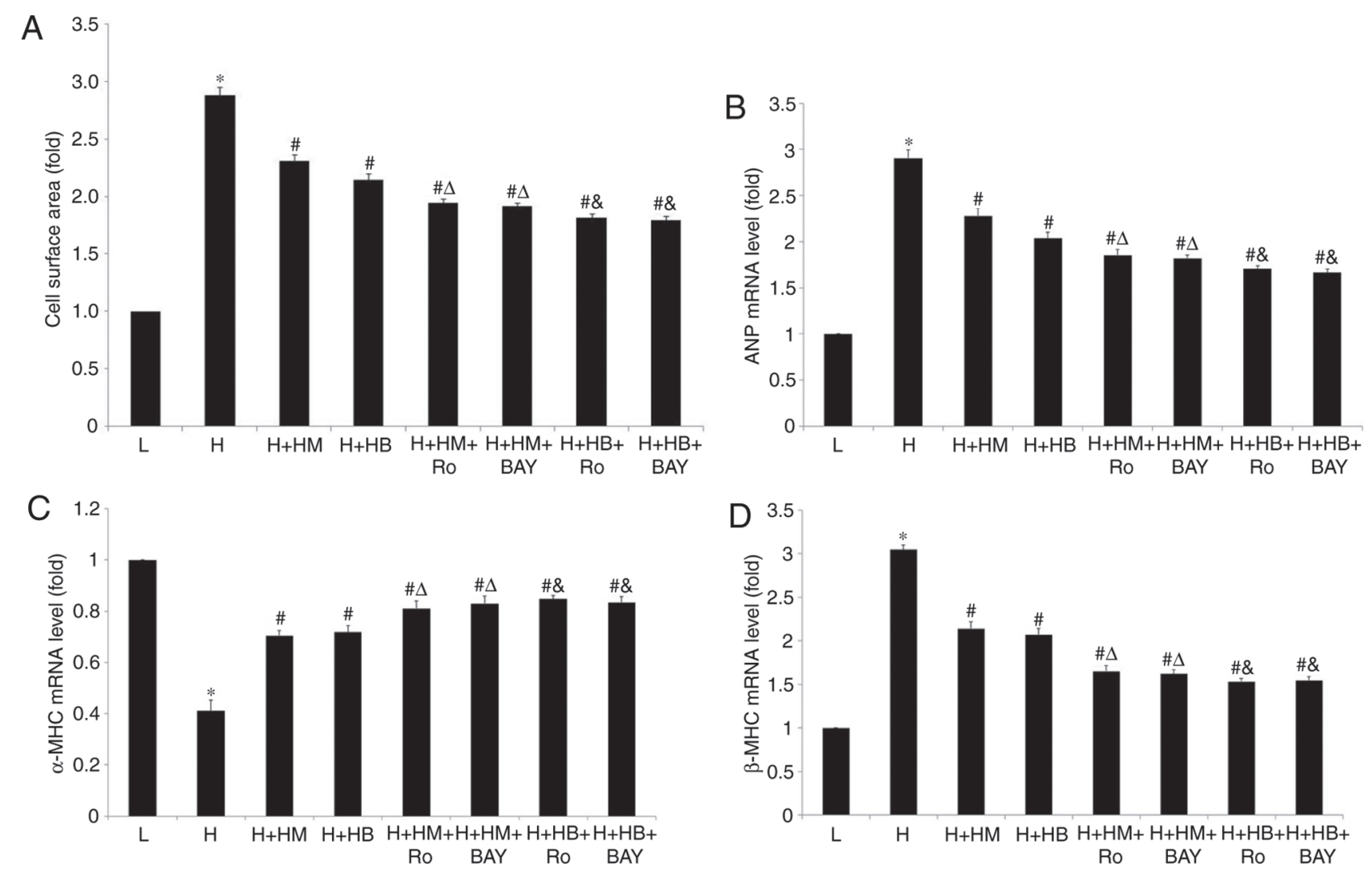

Figure 7. Combined use of PKC inhibitor Ro-31-8220 or NF-kB inhibitor BAY11-7082 with metoprolol or bisoprolol further decreases cell surface area, ANP and $\beta$-MHC mRNA levels and increases $\alpha$-MHC mRNA levels of cardiomyocytes cultured in high glucose. (A) Cell surface area. mRNA expression levels of (B) ANP, (C) $\alpha$-MHC and (D) $\beta$-MHC. $\mathrm{n}=100$ cardiomyocytes for measurement of each group. ${ }^{*} \mathrm{P}<0.05$ vs. $\mathrm{L}$ group, ${ }^{*} \mathrm{P}<0.05$ vs. $\mathrm{H}$ group, ${ }^{\Delta} \mathrm{P}<0.05$ vs. $\mathrm{HG}+\mathrm{HM}$ group, ${ }^{\&} \mathrm{P}<0.05$ vs. HG + HB group. L, low glucose; H, high glucose; LM, low metoprolol dose; HM, high metoprolol dose; LB, low bisoprolol dose; HB, high bisoprolol dose; Ro, Ro-31-8220; BAY, BAY11-7082; ANP, atrial natriuretic peptide; MHC, myosin heavy chain; PKC, protein kinase C.
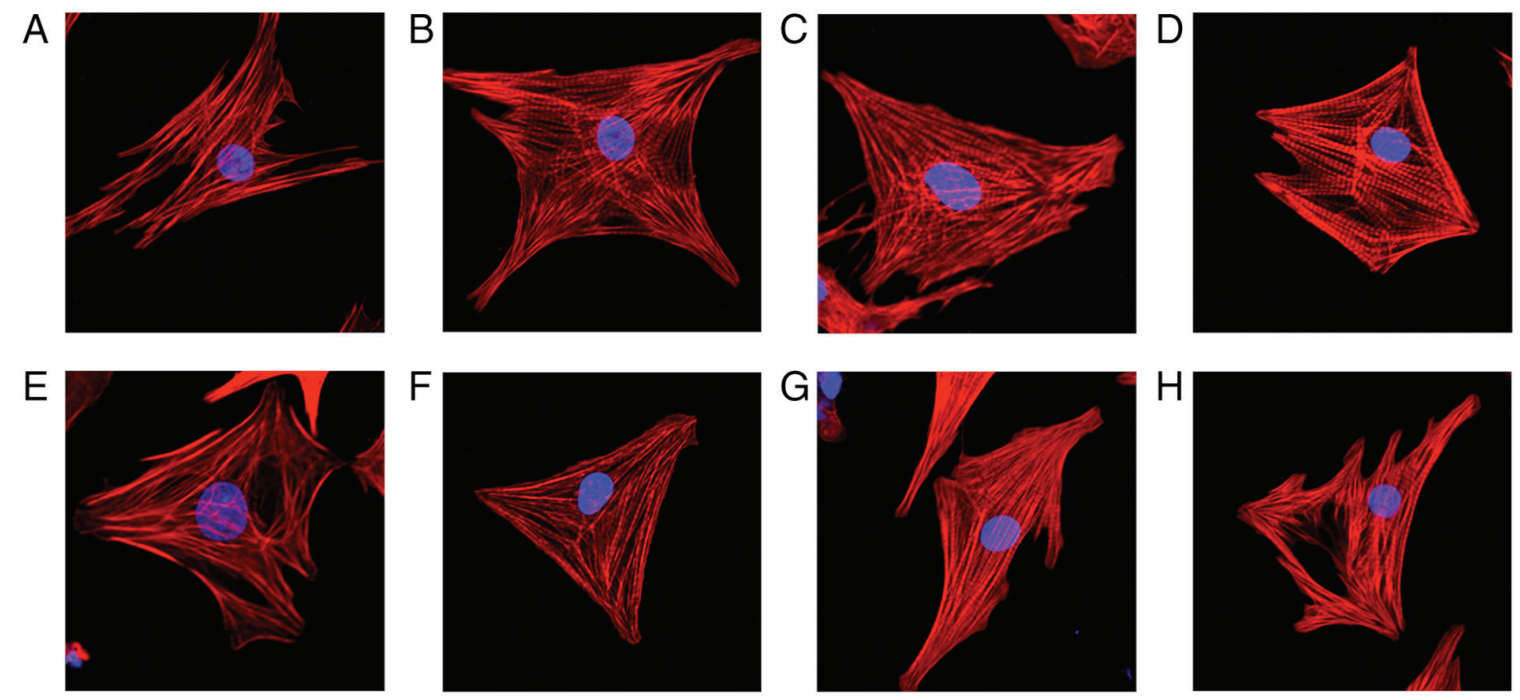

Figure 8. Representative image of the effects of metoprolol, bisoprolol, PKC inhibitor Ro-31-8220 and NF-kB inhibitor BAY11-7082 on the cell surface area of cardiomyocytes cultured in High glucose. The cell surface area of cardiomyocytes cultured (A) low glucose was significantly smaller compared with those cultured in (B) high glucose. High dose of (C) metoprolol and (D) bisoprolol treatment reduced the cell surface area of cardiomyocytes cultured in high glucose. Combined use of metoprolol and (E) PKC inhibitor Ro-31-8220 or (F) NF-kB inhibitor BAY11-7082 decreased the cell surface area compared with cardiomyocytes cultured in high glucose and metoprolol. Combined use of bisoprolol and (G) PKC inhibitor Ro-31-8220 or (H) NF-kB inhibitor BAY11-7082 further decreased the cell surface area compared with cardiomyocytes cultured in high glucose and bisoprolol. PKC, protein kinase $\mathrm{C}$.

PKC inhibitors, such hypertrophic alteration in cardiomyocytes were reversed. In addition, cardiac hypertrophy in ischemic and heart failure models usually resulted in the activation of NF- $\mathrm{BB}$ and TNF- $\alpha(31,32)$. Hence, these factors may play a role in the pathological development of diabetic cardiomyopathy. 
Table IV. Combined use of protein kinase C inhibitor Ro-31-8220 or NF-кB inhibitor BAY11-7082 with metoprolol or bisoprolol further decreased the pulsatile frequency and cellular diameter of cardiomyocytes cultured in high glucose.

\begin{tabular}{lcc}
\hline Treatment & Pulsatile frequency $(\mathrm{bpm})$ & Diameter $(\mu \mathrm{m})$ \\
\hline Low glucose $(5.5 \mathrm{mmol} / \mathrm{l})$ & $57.22 \pm 1.69$ & $18.16 \pm 0.78$ \\
High glucose $(25.5 \mathrm{mmol} / \mathrm{l})$ & $69.85 \pm 1.87^{\mathrm{a}}$ & $25.02 \pm 0.19^{\mathrm{a}}$ \\
High glucose + metoprolol $(10 \mu \mathrm{mol} / \mathrm{l})$ & $62.23 \pm 1.58^{\mathrm{b}}$ & $20.71 \pm 0.17^{\mathrm{b}}$ \\
High glucose + bisoprolol $(200 \mathrm{nmol} / \mathrm{l})$ & $61.75 \pm 1.63^{\mathrm{b}}$ & $20.44 \pm 0.36^{\mathrm{b}}$ \\
High glucose + metoprolol+Ro-31-8220 & $60.29 \pm 1.16^{\mathrm{b}, \mathrm{c}}$ & $19.03 \pm 0.55^{\mathrm{b}, \mathrm{c}}$ \\
High glucose + metoprolol+BAY11-7082 & $60.13 \pm 1.79^{\mathrm{b}, \mathrm{c}}$ & $19.14 \pm 0.41^{\mathrm{b}, \mathrm{c}}$ \\
High glucose + bisoprolol+Ro-31-8220 & $59.68 \pm 1.82^{\mathrm{b}, \mathrm{d}}$ & $18.76 \pm 0.63^{\mathrm{b}, \mathrm{d}}$ \\
High glucose + bisoprolol+BAY11-7082 & $59.56 \pm 1.67^{\mathrm{b}, \mathrm{d}}$ & $18.62 \pm 0.38^{\mathrm{b}, \mathrm{d}}$ \\
\hline
\end{tabular}

Data are presented as the mean $\pm \mathrm{SD}$ ( $\mathrm{n}=100$ cardiomyocytes for measurement of each group). ${ }^{\mathrm{a}} \mathrm{P}<0.05$ vs. LG glucose, ${ }^{\mathrm{b}} \mathrm{P}<0.05$ vs. $\mathrm{HG}$ group, ${ }^{\mathrm{c}} \mathrm{P}<0.05 \mathrm{vs} . \mathrm{HG}+$ metoprolol $(10 \mu \mathrm{mol} / \mathrm{l})$ group, ${ }^{\mathrm{d}} \mathrm{P}<0.05 \mathrm{vs} . \mathrm{HG}+$ bisoprolol $(200 \mathrm{nmol} / \mathrm{l})$ group.

Table V. Combined use of protein kinase C inhibitor Ro-31-8220 or NF- $\kappa$ B inhibitor BAY11-7082 with metoprolol or bisoprolol further decreased the total protein content and $\left[{ }^{3} \mathrm{H}\right]$-leucine incorporation of cardiomyocytes cultured in high glucose.

\begin{tabular}{lcc}
\hline Treatment & Protein $(\mu \mathrm{g} /$ well $)$ & {$\left[{ }^{3} \mathrm{H}\right]$-leucine incorporation $(\mathrm{cpm} /$ well $)$} \\
\hline Low glucose $(5.5 \mathrm{mmol} / \mathrm{l})$ & $30.74 \pm 3.25$ & $984.52 \pm 74.48$ \\
High glucose $(25.5 \mathrm{mmol} / \mathrm{l})$ & $58.54 \pm 4.87^{\mathrm{a}}$ & $1,578.93 \pm 69.23^{\mathrm{a}}$ \\
High glucose + metoprolol $(10 \mu \mathrm{mol} / \mathrm{l})$ & $40.35 \pm 4.66^{\mathrm{b}}$ & $1,201.67 \pm 76.53^{\mathrm{b}}$ \\
High glucose + bisoprolol $(200 \mathrm{nmol} / \mathrm{l})$ & $40.16 \pm 3.32^{\mathrm{b}}$ & $1,189.38 \pm 68.39^{\mathrm{b}}$ \\
High glucose + metoprolol+Ro-31-8220 & $37.61 \pm 3.91^{\mathrm{b}, \mathrm{c}}$ & $1,065.36 \pm 54.64^{\mathrm{b}, \mathrm{c}}$ \\
High glucose + metoprolol+BAY11-7082 & $36.82 \pm 3.58^{\mathrm{b}, \mathrm{c}}$ & $1,052.81 \pm 62.71^{\mathrm{b}, \mathrm{c}}$ \\
High glucose + bisoprolol+Ro-31-8220 & $37.45 \pm 3.34^{\mathrm{b}, \mathrm{d}}$ & $1,071.27 \pm 66.42^{\mathrm{b}, \mathrm{d}}$ \\
High glucose + bisoprolol+BAY11-7082 & $36.78 \pm 3.79^{\mathrm{b}, \mathrm{d}}$ & $1,045.65 \pm 59.16^{\mathrm{b}, \mathrm{d}}$ \\
\hline
\end{tabular}

Data are presented as the mean $\pm \mathrm{SD}\left(\mathrm{n}=100\right.$ cardiomyocytes for measurement of each group). ${ }^{\mathrm{a}} \mathrm{P}<0.05$ vs. $\mathrm{LG}$ group, ${ }^{\mathrm{b}} \mathrm{P}<0.05$ vs. $\mathrm{HG}$ group, ${ }^{\mathrm{c}} \mathrm{P}<0.05 \mathrm{vs}$. $\mathrm{HG}+$ metoprolol $(10 \mu \mathrm{mol} / \mathrm{l})$ group, ${ }^{\mathrm{d}} \mathrm{P}<0.05 \mathrm{vs} . \mathrm{HG}+$ bisoprolol $(200 \mathrm{nmol} / \mathrm{l})$ group.

In the present study, the expression levels of PKC- $\alpha$, PKC- $\beta_{2}, N F-\kappa B, T N F-\alpha$ and c-fos of cardiomyocytes cultured in HG were all upregulated compared with LG. The increased pulsatile frequency and hypertrophic changes, including cellular diameter, cell surface area, protein content and synthesis and mRNA levels of ANP, $\alpha$-MHC, $\beta$-MHC of cardiomyocytes treated with $\mathrm{HG}$ were reversed upon treatment with the PKC inhibitor Ro-31-8220. The expression and activity of PKC- $\alpha$ and PKC- $\beta_{2}$ significantly decreased, alongside reduced expression of $\mathrm{NF}-\kappa \mathrm{B}, \mathrm{TNF}-\alpha$, and $\mathrm{c}-\mathrm{fos}$ levels. Although it was reported that Ro-31-8220 inhibited glycogen synthase kinase-3 (33), there was no doubt that PKC inhibition was its principal effect as RO-31-8220 is widely accepted as a PKC inhibitor (34). The present results suggested that the pricinple effect of Ro-31-8220 may be mediated by PKC inhibition rather than GSK-3 inhibition, as shown by the suppression of the total and phosphrylated PKC- $\alpha$ and PKC $\beta_{2}$. Likewise, following treatment with the NF- $\mathrm{KB}$ inhibitor BAY11-7082, the $\mathrm{HG}$-induced increase in pulsatile frequency and cardiac hypertrophy was reversed, and a significant decrease in expression of NF- $\mathrm{B}$, TNF- $\alpha$, and c-fos levels was observed.
$\mathrm{NF}-\kappa \mathrm{B}$ is a key transcription factor regulating inflammatory responses and the expression of hyperglycemic stress related immediate early genes (35). Previous studies showed that $N F-\kappa B$ regulated several signal transduction pathways in cardiomyocytes under stimulation with $\mathrm{HG}(36,37)$. Hence, blocking NF- $\kappa \mathrm{B}$ might attenuate $\mathrm{HG}$-induced cardiac hypertrophy (38) in cardiac hypertrophy models. TNF- $\alpha$ is a cytokine associated with $\mathrm{NF}-\kappa \mathrm{B}$. As a contributor of cardiac dysfunction, elevated TNF- $\alpha$ level could trigger NF- $\kappa$ B translocation to the nucleus, allowing $\mathrm{NF}-\kappa \mathrm{B}$ to promote transcription of TNF- $\alpha(39,40)$.

c-fos is a proto-oncogene, whose activation could induce the enlargement of cardiomyocytes and increased protein content. TNF- $\alpha$ stimulates the expression of c-fos as an adaptive response to cardiac dysfunction, such as cardiac hypertrophy and ischemic heart disease $(41,42)$. Moreover, previous studies demonstrated that c-fos is also regulated by PKC to participate in inendothelin-1-induced proliferation of neonatal cardiomyocytes $(43,44)$. A previous study also revealed that the $\mathrm{PKC} / \mathrm{c}$-fos pathway was involved in $\mathrm{HG}$-induced cardiac hypertrophy (11). 
Beta-blockers are well studied and play a cardioprotective role in ameliorating cardiac dysfunction in rats with diabetic cardiomyopathy (45-47). Since numerous types of beta-blockers with different effects on glucose control are available at present, it would be beneficial for DM patients to select the appropriate beta-blocker to prevent or delay cardiovascular complication (48). According to evidence-based medicine, metoprolol and bisoprolol are two types of highly selective beta-blockers widely used in clinical practice (49). Autoantibodies against the $\beta 1$ receptor could be a predictor for left ventricular hypertrophy for T2DM patients with hypertension $(50,51)$. Treatment with metoprolol could inhibit intrinsic damage to the heart during diabetic cardiomyopathy (52). Several studies indicated that use of beta-blockers, such as bisoprolol, did not aggravate glycemic control, lipid profile or albuminuria status in T2DM patients with $\operatorname{SHF}(53,54)$.

To explore whether the protective effects of metoprolol and bisoprolol were associated with the PKC signal transduction pathway, expression and activation of two PKC isoforms (PKC- $\alpha$ and PKC- $\beta_{2}$ ) were detected in cardiomyocytes cultured with HG. Metoprolol and bisoprolol were found to decrease cellular pulsatile frequency and improve cardiac hypertrophy, and decrease expression and activity of PKC- $\alpha$. These changes were more significant when cultures were treated with a higher dose of metoprolol and bisoprolol. Meanwhile, the expression of p-PKC- $\beta_{2}$ decreased when cells were treated with higher doses of metoprolol and bisoprolol compared with cells treated with HG. However, when treated with a lower dose of metoprolol and bisoprolol, the expression of p-PKC- $\beta_{2}$ in cardiomyocytes resulted in no significant change when compared with HG-treated samples, while the expression and activation of PKC- $\alpha$ of HG cultured cardiomyocytes were significantly inhibited by treatment with metoprolol or bisoprolol compared with those cultured with HG alone. Therefore, the protective role of metoprolol and bisoprolol on HG-induced hypertrophy was mainly conducted by inhibition of PKC- $\alpha$. Expression of NF- $\kappa B, T N F-\alpha$ and $c-$ fos also significantly decreased when treated with metoprolol and bisoprolol. The present results suggested that high dose of bisoprolol could further inhibit the decrease in TNF- $\alpha$ expression leve in the low bisoprolol dose group. In addition, higher doses of metoprolol and bisoprolol showed a significant suppressive effect on c-fos expression compared with low doses. Collectively, metoprolol and bisoprolol provided a protective role against diabetic cardiomyopathy via the PKC-induced NF- $\mathrm{BB} / \mathrm{TNF}-\alpha / \mathrm{c}$-fos signal transduction pathway.

In the current study, high dose of metoprolol and bisoprolol inhibited c-fos expression to a lower degree compared with $\mathrm{PKC}$ or NF-KB inhibitor, although the differences were not significant. The present data suggested that beta-blockers may have other targets other than PKC and NF- $\mathrm{KB}$. One explanation for the results is the involvement of another important cardiac hypertrophic pathway in cultured cardiomyocytes, the PKC- $\delta$ /protein kinase D (PKD)/histone deacetylases (HDAC) pathway. PKD, which can be phosphorylated by $\mathrm{PKC}-\delta$, regulates the ability of cardiomyocyte growth and contractility through phosphorylation of proteins such as class IIa HDACs (55). Metoprolol and bisoprolol may inhibit the expression of c-fos through regulating the PKC- $\delta$ signaling pathways. Although there is little evidence of the effects of signal transduction pathways of beta-blockers on the expression of c-fos, one study showed that bisoprolol, especially at high doses, could increase the survival rate of hypertensive diastolic heart failure model of rats, at least partly through the alleviation of inflammatory changes (interleukin- $1 \beta$, transforming growth factor- $\beta 1$ and monocyte chemoattractant protein-1) and oxidative stress (reactive oxygen species production and nicotinamide adenine dinucleotide phosphate oxidase activity) (52). Moreover, isoproterenol (ISO)-induced heart failure could be inhibited by a Rho-associated protein kinase (ROCK) inhibitor, fasudil, which suppressed isoproterenol-induced JNK activation, translocation of ERK to the nucleus, and increased expression of c-fos and c-jun through RhoA/ROCK. Consequently, those changes could suppress ISO-induced cardiac hypertrophy and ventricular remodeling in rat models (56). Since ISO-induced heart dysfunction was associated with RhoA/ROCK and its downstream signaling pathways, beta-blockers may also have protective effects on cardiomyocytes through similar signaling pathways, although this warrants further studies.

Activation of PI3K-Akt and ERK pathways may also contribute to the cardiac protective effects of metoprolol (57). Therefore, beta-blockers may have other targets than PKC and NF- $\mathrm{kB}$, and ERK and inflammatory cytokines could also cause cardiomyocyte hypertrophy. Fujioka et al (58) proposed that the use of another beta-blocker, propranolol, could promote post-hypoxic contractile and metabolic recovery via non-beta-adrenoreceptors in ischemia-reperfusion rat hearts. Hence, the role of such non-beta-adrenorecepors activated by beta-blockers could be further investigated in diabetic cardiomyopathy. In the present study, combined use of PKC inhibitor Ro-31-8220 or NF- $\kappa$ B inhibitor BAY11-7082 with metoprolol further decreased the cellular pulsatile frequency, cellular diameter, cell surface area, total protein content and $\left[{ }^{3} \mathrm{H}\right]$-leucine incorporation of cardiomyocytes cultured with HG. The same result was observed when bisoprolol was combined with Ro-31-8220 or BAY11-7082. Combined use of beta-blockers with PKC or NF- $\mathrm{kB}$ inhibitor attenuated cardiac hypertrophy caused by HG. Beta-blockers may have targets other than PKC and NF- $\mathrm{KB}$ that could also inhibit the expression of c-fos. This hypothesis supports the observation that high doses of metoprolol and bisoprolol may inhibit c-fos expression to a lower degree than PKC or NF- $\mathrm{KB}$ inhibitors, although the differences were not statistically significant in the present study.

In conclusion, the data presented depicted that hyperglycemia could activate the PKC/NF- $\kappa \mathrm{B} / \mathrm{TNF}-\alpha / \mathrm{c}$-fos signal transduction pathway in diabetic cardiomyopathy. The protective role of metoprolol and bisoprolol could significantly reverse cardiac dysfunction and hypertrophy. Future studies can be performed to identify other targets of beta-blockers and non-beta receptor-mediated effects of beta-blockers in diabetic cardiomyocytes.

\section{Acknowledgements}

Not applicable.

\section{Funding}

This work was supported by the National Natural Science Foundation of China (grant nos. 81500212 
and 81800212) and Zhejiang Natural Science Foundation (grant nos. LY18H020007 and LQ16H020001).

\section{Availability of data and materials}

The datasets used and/or analyzed during the current study are available from the corresponding author on reasonable request.

\section{Authors' contributions}

MW, GF and WZ designed the research. MW, QL, YW and ZL performed the research. WZ contributed new reagents or analytic tools. MW, LZ, YL and WZ analyzed the data. MW, QL and YL wrote the manuscript. All authors read and approved the final manuscript.

\section{Ethics approval and consent to participate}

All procedures were approved by the Ethics Committee for the Use of Experimental Animals in Zhejiang University. All the experiments followed the instructions for animal care and usage provided by Zheijiang University.

\section{Patient consent for publication}

Not applicable.

\section{Competing interests}

The authors declare that they have no competing interests.

\section{References}

1. Whiting DR, Guariguata L, Weil C and Shaw J: IDF diabetes atlas: Global estimates of the prevalence of diabetes for 2011 and 2030. Diabetes Res Clin Pract 94: 311-321, 2011.

2. Jia G, Whaley-Connell A and Sowers JR: Diabetic cardiomyopathy: A hyperglycaemia- and insulin-resistance-induced heart disease. Diabetologia 61: 21-28, 2018.

3. Suhara T, Baba Y, Shimada BK, Higa JK and Matsui T: The mTOR signaling pathway in myocardial dysfunction in type 2 diabetes mellitus. Curr Diab Rep 17: 38, 2017.

4. Gao JR, Qin XJ, Fang ZH, Li-Shan, Han LP, Hui-Jiang, Guo MF and Jiang NN: To explore the pathogenesis of vascular lesion of type 2 diabetes mellitus based on the PI3K/Akt signaling pathway. J Diabetes Res 2019: 4650906, 2019.

5. Wang WK, Lu QH, Wang X, Wang B, Wang J, Gong HP, Wang L, $\mathrm{Li} \mathrm{H}$ and Du YM: Ulinastatin attenuates diabetes-induced cardiac dysfunction by the inhibition of inflammation and apoptosis. Exp Ther Med 14: 2497-2504, 2017.

6. Brownlee M: The pathobiology of diabetic complications A unifying mechanism. Diabetes 54: 1615-1625, 2005.

7. Ferreira JC, Brum PC and Mochly-Rosen D: $\beta$ IIPKC and EPKC isozymes as potential pharmacological targets in cardiac hypertrophy and heart failure. J Mol Cell Cardiol 51: 479-484, 2011.

8. Churchill EN and Mochly-Rosen D: The roles of PKCdelta and epsilon isoenzymes in the regulation of myocardial ischaemia/reperfusion injury. Biochem Soc Trans 35: 1040-1042, 2007.

9. Weng LQ, Zhang WB, Ye Y, Yin PP, Yuan J, Wang XX, Kang L, Jiang SS, You JY, Wu J, et al: Aliskiren ameliorates pressure overload-induced heart hypertrophy and fibrosis in mice. Acta Pharmacol Sin 35: 1005-1014, 2014.

10. Das Evcimen $\mathrm{N}$ and King GL: The role of protein kinase $\mathrm{C}$ activation and the vascular complications of diabetes. Pharmacol Res 55: 498-510, 2007.

11. Min W, Bin ZW, Quan ZB, Hui ZJ and Sheng FG: The signal transduction pathway of PKC/NF-kappa B/c-fos may be involved in the influence of high glucose on the cardiomyocytes of neonatal rats. Cardiovasc Diabetol 8: 8, 2009.
12. Norozi K: The role of beta-blocker in heart failure in adults with congenital heart disease. Rev Recent Clin Trials 9: 64-67, 2014.

13. Chia N, Fulcher J and Keech A: Beta-blocker, angiotensin-converting enzyme inhibitor/angiotensin receptor blocker, nitrate-hydralazine, diuretics, aldosterone antagonist, ivabradine, devices and digoxin [BANDAID(2)]: An evidence-based mnemonic for the treatment of systolic heart failure. Intern Med J 46: 653-662, 2016.

14. Spoladore R, Fragasso G, Perseghin G, De Cobelli F, Esposito A, Maranta F, Calori G, Locatelli M, Lattuada G, Scifo P, et al: Beneficial effects of beta-blockers on left ventricular function and cellular energy reserve in patients with heart failure. Fundam Clin Pharmacol 27: 455-464, 2013.

15. Tsujimoto T, Sugiyama T, Shapiro MF, Noda M and Kajio H: Risk of cardiovascular events in patients with diabetes mellitus on beta-blockers. Hypertension 70: 103-110, 2017.

16. Bakris GL, Fonseca V, Katholi RE, McGill JB, Messerli FH, Phillips RA, Raskin P, Wright JT Jr, Oakes R, Lukas MA, et al: Metabolic effects of carvedilol vs. metoprolol in patients with type 2 diabetes mellitus and hypertension: A randomized controlled trial. JAMA 292: 2227-2236, 2004.

17. Kveiborg B, Hermann TS, Major-Pedersen A, Christiansen B, Rask-Madsen C, Rauns $\varnothing$ J, Køber L, Torp-Pedersen C and Dominguez H: Metoprolol compared to carvedilol deteriorates insulin-stimulated endothelial function in patients with type 2 diabetes-a randomized study. Cardiovasc Diabetol 9: 21, 2010.

18. Haas SJ, Vos T, Gilbert RE and Krum H: Are beta-blockers as efficacious in patients with diabetes mellitus as in patients without diabetes mellitus who have chronic heart failure? A meta-analysis of large-scale clinical trials. Am Heart J 146: 848-853, 2003.

19. Rengo G, Cannavo A, Liccardo D, Zincarelli C, de Lucia C, Pagano G, Komici K, Parisi V, Scala O, Agresta A, et al: Vascular endothelial growth factor blockade prevents the beneficial effects of beta-blocker therapy on cardiac function, angiogenesis, and remodeling in heart failure. Circ Heart Fail 6: 1259-1267, 2013.

20. Li X, Zhang X, Wang T, Sun C, Jin T, Yan H, Zhang J, Li X, Geng T, Chen C, et al: Regulation by bisoprolol for cardiac microRNA expression in a rat volume-overload heart failure model. J Nanosci Nanotechnol 13: 5267-5275, 2013.

21. Cheng K, Wei MQ, Jia GL, Wang HC, Luan RH, Guo WY, Li WJ, Zong XJ and Zhou X: Effects of metoprolol and small intestine RNA on marrow-derived endothelial progenitor cells applied for autograft transplantation in heart disease. Eur Rev Med Pharmacol Sci 18: 1666-1673, 2014.

22. Garcia-Egido A, Andrey JL, Puerto JL, Aranda RM, Pedrosa MJ, López-Sáez JB, Rosety M and Gomez F: Beta-blocker therapy and prognosis of heart failure patients with new-onset diabetes mellitus. Int J Clin Pract 69: 550-559, 2015.

23. Couto $M$ and Cates $C$ : Laboratory guidelines for animal care. Methods Mol Biol 1920: 407-430, 2019.

24. Shen YX, Xiao K, Liang P, Ma YW and Huang X: Improvement on the modified Lowry method against interference of divalent cations in soluble protein measurement. Appl Microbiol Biotechnol 97: 4167-4178, 2013.

25. Lekawanvijit S, Adrahtas A, Kelly DJ, Kompa AR, Wang BH and Krum H: Does indoxyl sulfate, a uraemic toxin, have direct effects on cardiac fibroblasts and myocytes? Eur Heart J 31: 1771-1779, 2010

26. Luo JD, Xie F, Zhang WW, Ma XD, Guan JX and Chen X: Simvastatin inhibits noradrenaline-induced hypertrophy of cultured neonatal rat cardiomyocytes. Br J Pharmacol 132: 159-164, 2001.

27. Nishiga M, Horie T, Kuwabara Y, Nagao K, Baba O, Nakao T, Nishino T, Hakuno D, Nakashima Y, Nishi H, et al: MicroRNA-33 controls adaptive fibrotic response in the remodeling heart by preserving lipid raft cholesterol. Circ Res 120: 835-847, 2017.

28. Wang M, Zhang WB, Zhu JH, Fu GS and Zhou BQ: Breviscapine ameliorates hypertrophy of cardiomyocytes induced by high glucose in diabetic rats via the PKC signaling pathway. Acta Pharmacol Sin 30: 1081-1091, 2009.

29. Wang M, Zhang WB, Zhu JH, Fu GS and Zhou BQ: Breviscapine ameliorates cardiac dysfunction and regulates the myocardial $\mathrm{Ca}(2+)$-cycling proteins in streptozotocin-induced diabetic rats. Acta Diabetol 47 (Suppl 1): S209-S218, 2010.

30. Song X, Qian X, Shen M, Jiang R, Wagner MB, Ding G, Chen G and Shen B: Protein kinase $C$ promotes cardiac fibrosis and heart failure by modulating galectin-3 expression. Biochim Biophys Acta 1853: 513-521, 2015. 
31. Kawamura N, Kubota T, Kawano S, Monden Y, Feldman AM Tsutsui H, Takeshita A and Sunagawa K: Blockade of NF-kappaB improves cardiac function and survival without affecting inflammation in TNF-alpha-induced cardiomyopathy. Cardiovase Res 66: 520-529, 2005.

32. Lu J, Liu F, Chen F, Jin Y, Chen H, Liu D and Cui W: Amlodipine and atorvastatin improve ventricular hypertrophy and diastolic function via inhibiting TNF- $\alpha$, IL- $1 \beta$ and NF- $\mathrm{BB}$ inflammatory cytokine networks in elderly spontaneously hypertensive rats. Biomed Pharmacother 83: 330-339, 2016.

33. Hers I, Tavaré JM and Denton RM: The protein kinase C inhibitors bisindolylmaleimide I (GF 109203x) and IX (Ro 31-8220) are potent inhibitors of glycogen synthase kinase-3 activity. FEBS Lett 460: 433-436, 1999.

34. Catley MC, Cambridge LM, Nasuhara Y, Ito K, Chivers JE, Beaton A, Holden NS, Bergmann MW, Barnes PJ and Newton R: Inhibitors of protein kinase $\mathrm{C}$ (PKC) prevent activated transcription: Role of events downstream of NF-kappaB DNA binding. J Biol Chem 279: 18457-18466, 2004.

35. Abe J: Role of PKCs and NF-kappaB activation in myocardial inflammation: Enemy or ally? J Mol Cell Cardiol 43: 404-408, 2007.

36. Guo Y, Zhuang X, Huang Z, Zou J, Yang D, Hu X, Du Z, Wang L and Liao X: Klotho protects the heart from hyperglycemia-induced injury by inactivating ROS and NF- $\kappa \mathrm{B}$-mediated inflammation both in vitro and in vivo. Biochim Biophys Acta Mol Basis Dis 1864: 238-251, 2018.

37. Ren XM, Zuo GF, Wu W, Luo J, Ye P, Chen SL and Hu ZY: Atorvastatin alleviates experimental diabetic cardiomyopathy by regulating the GSK-3 $\beta-\mathrm{PP} 2 \mathrm{Ac}-\mathrm{NF}-\kappa \mathrm{B}$ signaling axis. PLoS One 11: e0166740, 2016.

38. Freund C, Schmidt-Ullrich R, Baurand A, Dunger S, Schneider W, Loser P, El-Jamali A, Dietz R, Scheidereit C and Bergmann MW: Requirement of nuclear factor-kappaB in angiotensin II- and isoproterenol-induced cardiac hypertrophy in vivo. Circulation 111: 2319-2325, 2005.

39. Higuchi Y, Otsu K, Nishida K, Hirotani S, Nakayama $H$, Yamaguchi $\mathrm{O}$, Matsumura $\mathrm{Y}$, Ueno $\mathrm{H}$, Tada $\mathrm{M}$ and Hori $\mathrm{M}$ : Involvement of reactive oxygen species-mediated NF-kappa B activation in TNF-alpha-induced cardiomyocyte hypertrophy. J Mol Cell Cardiol 34: 233-240, 2002.

40. Higuchi Y, Chan TO, Brown MA, Zhang J, DeGeorge BR Jr, Funakoshi H, Gibson G, McTiernan CF, Kubota T, Jones WK and Feldman AM: Cardioprotection afforded by NF-kappaB ablation is associated with activation of Akt in mice overexpressing TNF-alpha. Am J Physiol Heart Circ Physiol 290: H590-H598, 2006

41. Hattori Y,HattoriS, Akimoto K, Nishikimi T, Suzuki K, Matsuoka H and Kasai K: Globular adiponectin activates nuclear factor-kappaB and activating protein-1 and enhances angiotensin II-induced proliferation in cardiac fibroblasts. Diabetes 56: 804-808, 2007.

42. Dawn B, Guo Y, Rezazadeh A, Wang OL, Stein AB, Hunt G, Varma J, Xuan YT, Wu WJ, Tan W, et al: Tumor necrosis factor-alpha does not modulate ischemia/reperfusion injury in naive myocardium but is essential for the development of late preconditioning. J Mol Cell Cardiol 37: 51-61, 2004

43. Zhu XX, Niu XL, Chen DZ, Zhou XD, Pei JM, Zhu MZ, Guo J, Zhu XL and Wang WQ: Inhibitory effects of rosiglitazone against endothelin-1-induced proliferation of rat cardiac myocytes: The role of PKC-c-fos pathway. Nan Fang Yi Ke Da Xue Xue Bao 28 1056-1060, 2008 (In Chinese).

44. Maniar R, Pecherskaya A, Ila R and Solem M: PKC alpha-dependent regulation of the IGF1 receptor in adult and embryonic rat cardiomyocytes. Mol Cell Biochem 275: 15-24, 2005.

45. Rizzi E, Guimaraes DA, Ceron CS, Prado CM, Pinheiro LC, Martins-Oliveira A, Gerlach RF and Tanus-Santos JE: $\beta 1$-Adrenergic blockers exert antioxidant effects, reduce matrix metalloproteinase activity, and improve renovascular hypertension-induced cardiac hypertrophy. Free Radic Biol Med 73: 308-317, 2014.
46. Amanfu RK and Saucerman JJ: Modeling the effects of $\beta 1$-adrenergic receptor blockers and polymorphisms on cardiac myocyte Ca2+ handling. Mol Pharmacol 86: 222-230, 2014.

47. Sharma V, Dhillon P, Wambolt R, Parsons H, Brownsey R, Allard MF and McNeill JH: Metoprolol improves cardiac function and modulates cardiac metabolism in the streptozotocin-diabetic rat. Am J Physiol Heart Circ Physiol 294: H1609-H1620, 2008.

48. Chen RJ, Chu H and Tsai LW: Impact of beta-blocker initiation timing on mortality risk in patients with diabetes mellitus undergoing noncardiac surgery: A nationwide population-based cohort study. J Am Heart Assoc 6: e004392, 2017.

49. Fröhlich H, Torres L, Täger T, Schellberg D, Corletto A, Kazmi S, Goode K, Grundtvig M, Hole T, Katus HA, et al: Bisoprolol compared with carvedilol and metoprolol succinate in the treatment of patients with chronic heart failure. Clin Res Cardiol 106 711-721,2017.

50. Arnold SV, Spertus JA, Lipska KJ, Lanfear DE, Tang F, Grodzinsky A, McGuire DK, Gore MO, Goyal A, Maddox TM and Kosiborod M: Type of $\beta$-blocker use among patients with versus without diabetes after myocardial infarction. Am Heart J 168: 273-279.e1, 2014.

51. Zhao L, Xu C and Xu J: Autoantibodies against $\beta 1$ receptor and AT1 receptor in type 2 diabetes patients with left ventricular dilatation. Cardiology 129: 191-196, 2014

52. Saran V, Sharma V, Wambolt R, Yuen VG, Allard M and McNeill JH: Combined metoprolol and ascorbic acid treatment prevents intrinsic damage to the heart during diabetic cardiomyopathy. Can J Physiol Pharmacol 92: 827-837, 2014.

53. Wai B, Kearney LG, Hare DL, Ord M, Burrell LM and Srivastava PM: Beta blocker use in subjects with type 2 diabetes mellitus and systolic heart failure does not worsen glycaemic control. Cardiovasc Diabetol 11: 14, 2012.

54. Hirst JA, Farmer AJ, Feakins BG, Aronson JK and Stevens RJ: Quantifying the effects of diuretics and $\beta$-adrenoceptor blockers on glycaemic control in diabetes mellitus-a systematic review and meta-analysis. Br J Clin Pharmacol 79: 733-743, 2015.

55. Phan D, Stratton MS, Huynh QK and McKinsey TA: A novel protein kinase $\mathrm{C}$ target site in protein kinase $\mathrm{D}$ is phosphorylated in response to signals for cardiac hypertrophy. Biochem Biophys Res Commun 411: 335-341, 2011.

56. Wang N, Guan P, Zhang JP, Li YQ, Chang YZ, Shi ZH, Wang FY and Chu L: Fasudil hydrochloride hydrate, a Rho-kinase inhibitor, suppresses isoproterenol-induced heart failure in rats via JNK and ERK1/2 pathways. J Cell Biochem 112: 1920-1929, 2011.

57. Kovacs K, Hanto K, Bognar Z, Tapodi A, Bognar E, Kiss GN, Szabo A, Rappai G, Kiss T, Sumegi B and Gallyas F Jr: Prevalent role of Akt and ERK activation in cardioprotective effect of $\mathrm{Ca}(2+)$ channel- and beta-adrenergic receptor blockers. Mol Cell Biochem 321: 155-164, 2009.

58. Fujioka H, Yoshihara S, Tanaka T, Fukumoto T, Kuroiwa A, Tanonaka K, Hayashi $\mathbf{M}$ and Takeo S: Enhancement of post-hypoxic contractile and metabolic recovery of perfused rat hearts by dl-propranolol: Possible involvement of non-beta-receptor mediated activity. J Mol Cell Cardiol 23: 949-962, 1991.

This work is licensed under a Creative Commons Attribution-NonCommercial-NoDerivatives 4.0 International (CC BY-NC-ND 4.0) License. 